\title{
Waste-Water Use in Energy Crops Production
}

\author{
Cecilia Rebora, Horacio Lelio, Luciana Gómez and Leandra Ibarguren \\ Facultad de Ciencias Agrarias - Universidad Nacional de Cuyo \\ Argentina
}

\section{Introduction}

\subsection{Waste water use in irrigation}

Water supply and water quality degradation are global concerns that will intensify with increasing water demand; for this reason, worldwide, marginal-quality water will become an increasingly important component of agricultural water supplies, particularly in waterscarce regions. The status of severe water resource shortage determines that new water source must be developed to cope with the deficiency of water sources for agriculture irrigation. One of the major types of marginal-quality water is the wastewater from urban and peri-urban areas (Pedrero et al., 2010). The municipal wastewater is a potential water resource with stability of water quantity and reliable supply. Irrigation with reclaimed municipal wastewater that is properly treated and satisfied with the agricultural recycling standards has huge benefits and profound social effects (Shi et al., 2008).

In recent years wastewater use has gained importance in water-scarce regions. In Pakistan $26 \%$ of national vegetable production is irrigated with wastewater (Ensink et al., 2004). In Ghana, informal irrigation involving diluted wastewater from rivers and streams occurs on an estimated 11,500 hectares, an area larger than the reported extent of formal irrigation in the country (Keraita and Drechsel, 2004). In Mexico about 260,000 hectares are irrigated with wastewater, mostly untreated (Mexico CAN, 2004).

Wastewater reuse in agriculture is an ancient practice that has been generally implemented worldwide. Agricultural deployment of wastewater for irrigation is based on the value of its constituents, which are used as fertilizers. However, crop irrigation with insufficiently treated wastewater may result in health risks. The use of sewage effluent for irrigation exposes the public to the dangers of infection with a variety of pathogens such as bacteria, viruses, protozoa and helminths. Thus the benefit of wastewater reuse is limited by its potential health hazards associated with the transmission of pathogenic organisms from the irrigated soil to crops, to grazing animals and humans (Gupta et al., 2009). Human health risks from wastewater irrigation include firstly farmers' and consumers' exposure to pathogens including helminth infections, and secondly, organic and inorganic trace elements. Protective measures such as wearing boots and gloves, and changing irrigation methods can reduce farmer exposure (Qadir et al., 2010).

\subsection{Energy crops and biofuels}

Energy crops, also called "bioenergy crops", are grown for the specific purpose of producing energy (electricity or liquid fuels). As these crops are not grown for the purpose of producing food, there are no health risks implicated for the consumers. 
The possibility of using biomass as a source of energy in reducing green-house gas emissions is a matter of great interest. In particular, biomass from agriculture represent one of the largest and most diversified sources to be exploited and more specifically, ethanol and diesel deriving from biomass have the potential to be a sustainable means of replacing fossil fuels for transportation (Singh et al., 2008; Dalla Marta et al., 2010).

These liquid biofuels are bioethanol (gasoline-equivalent) and biodiesel (diesel-equivalent). Bioethanol is used as an additive or substitute for gasoline, and biodiesel, alone or combined with diesel for diesel engines. The first is obtained from fermentation of grains such as maize starch-, sugar cane or reserve organs rich in carbohydrates (Jerusalem artichoke, sugar beet, among others). Biodiesel comes from vegetable oils through a chemical process called "transesterification" (Huergo, 2001).

Bioethanol is by far the most common biofuel in use worldwide. Global bioethanol production increased from 4.4 billion litres in 1980 to 46.2 billion litres in 2005 (Fig. 1). The largest producers of ethanol are United States, Brazil and China. Bioethanol is produced from the fermentation of starch or sugar-rich crops. Bioethanol can also be produced from cellulosic materials, such as trees, grasses, and agriculture residues. However, cellulosic ethanol is not yet commercially viable due to high production costs (Fulton et al., 2004; de Vries et al., 2010). Global biodiesel production increased from 11.4 million litres in 1991 to 3.9 billion litres in 2005. Germany, France, United States, and Italy are the leading producers of biodiesel. This biofuel can be produced from vegetable oil, used frying oil, or animal fat through a transesterification process in which oil molecules react with an alcohol and a catalyst to form fatty acid- methyl esters (FAME or biodiesel) and glycerol (Pin Koh and Ghazoul, 2008).

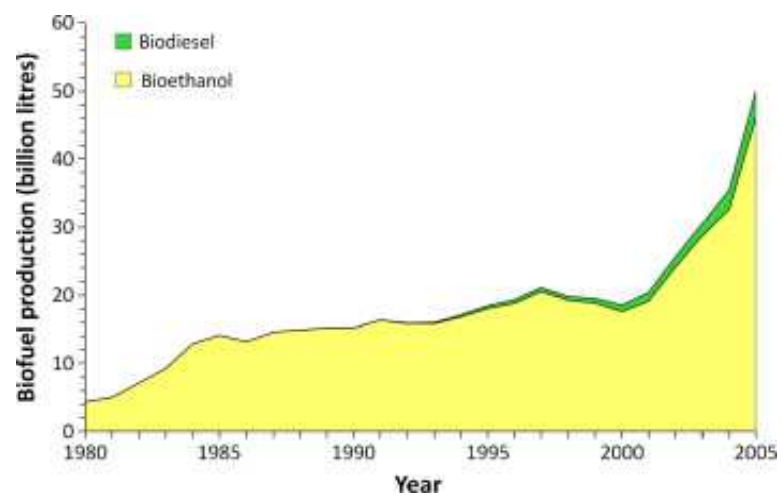

Fig. 1. Increase in global production of bioethanol and biodiesel between 1980 and 2005. Taken from Pin Koh and Ghazoul, 2008.

Argentina is today the fourth largest producer of biodiesel after the European Union, United States and Brazil. Most of Argentina's biodiesel is already destined to foreign markets. The Argentine biodiesel industry is mainly based on the use of soybean as feedstock. The ethanol production complex in Argentina is mainly comprised by sugar mills in the northwestern part of the country. However, the ethanol produced by these firms is not exclusively meant for fuel usage. In 2006, a large ethanol distillery was inaugurated in the Tucumán province, aimed at producing ethanol fuel for the domestic and export markets ${ }^{1}$.

${ }^{1}$ http://www.argentina.gov.ar/argentina/portal/papups/biofuels-opportunities.pdf 


\section{Waste water use in energy crops production in Mendoza, Argentina: research experience}

In Argentina we have no available data of wastewater use for irrigation; but information from Mendoza province is the following: $3.2 \mathrm{~m}^{3} / \mathrm{s}$ of domestic efluents are generated; it is estimated that 10,300 hectares are irrigated with urban waste water with different treatment level (G. Fasciolo, personal communication, 2010).

Mendoza weather conditions may be labeled 'warm-arid'. Annual rainfall ranges from 100 $\mathrm{mm}$ in the north, up to $400 \mathrm{~mm}$ in the south, with a mean annual temperature varying from $13^{\circ} \mathrm{C}$ in the south to $20^{\circ} \mathrm{C}$ in the north (Guevara, 1997). Irrigation is essential for crops production. The main species grown in Mendoza province are wine-grape, some fruit trees, and vegetables such as garlic, onion, potato and tomato.

In order not to compete for water with these traditional species, we studied energy crops production using waste water irrigation. Jerusalem artichoke (Helianthus tuberosus L.) and rape (Brassica napus L.) were selected for this study.

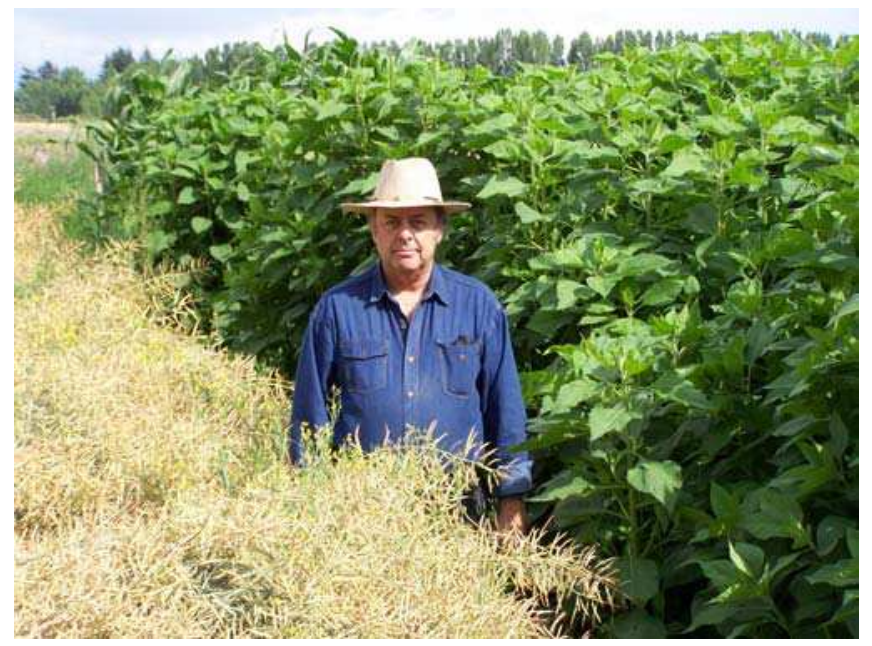

Photo 1. Horacio Lelio (one of the authors of this chapter) between the two energy crops tryed in our research, "rape" in the left and "Jerusalem artichoke" in the right, december 2008.

Jerusalem artichoke is a potentially useful crop for bioetanol production (Kays and Nottingham, 2008). Some studies indicate that 4,500 1 of ethanol can be produced from 50 tons of tubers. Rape oil can be used as raw material to produce biodiesel (de Vries, 2010).

\subsection{Brief characterization of the energy crops studied}

Brassica napus L. ("rape" or "canola") is a cultivated plant of the Brassica family. It is an annual plant that reaches 0.3 to $1 \mathrm{~m}$ tall, leaves are 5 to $40 \mathrm{~cm}$ long, flowering occurs in early spring with yellow flowers, the fruit is a siliqua from 5 to $7 \mathrm{~cm}$ with several seeds $1.5 \mathrm{~mm}$ in diameter.

Canola is the name given to certain varieties of oilseed rape. This name is a trademark for a hybrid variety of rape initially bred in Canada. 


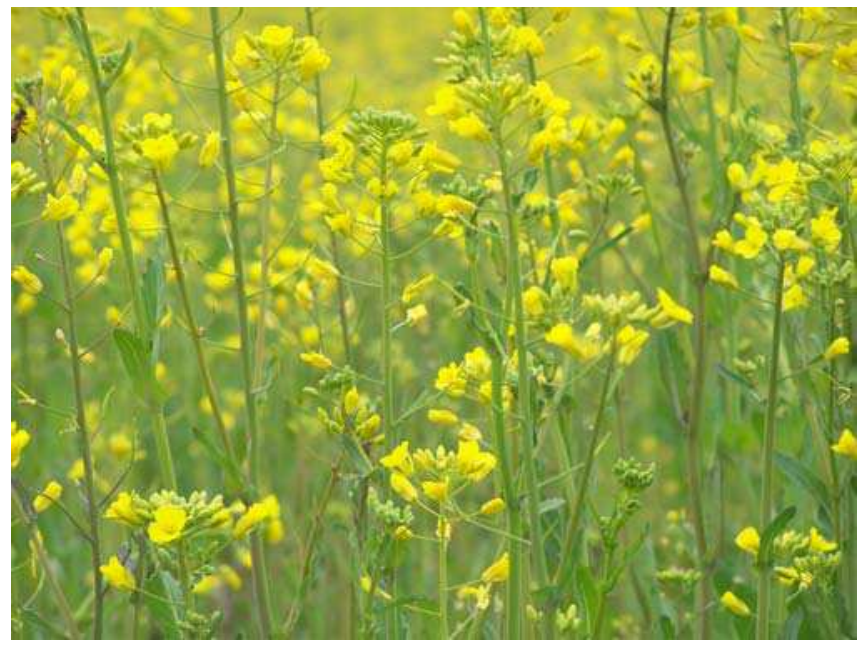

Photo 2. Rape in flower, spring 2008.

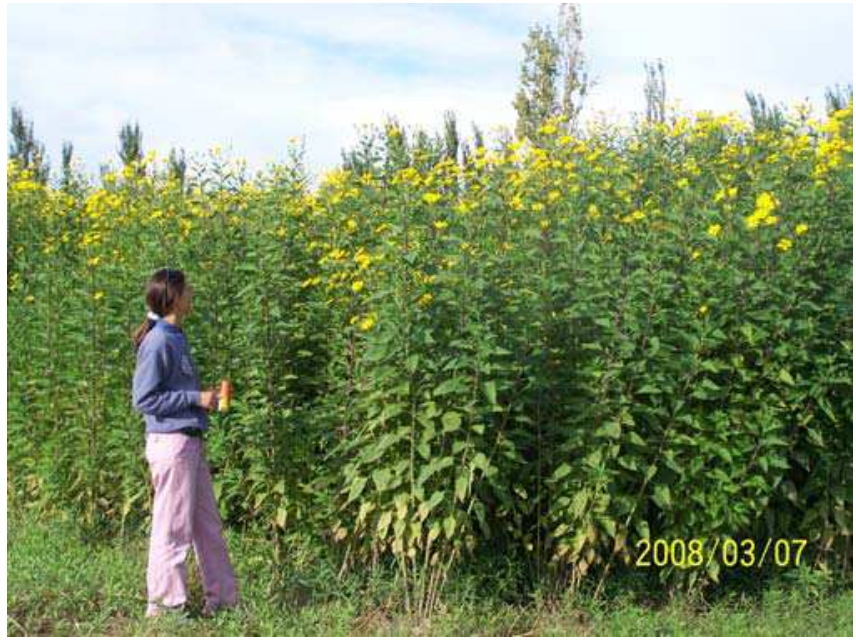

Photo 3. Jerusalem artichoke in flower, March 2008.

Rape is cultivated worldwide for forage, vegetable oil for human consumption and biodiesel. The major producers are the European Union, Canada, United States, Australia, China and India.

According to the United States Agriculture Department, rapeseed was the third largest source of vegetable oil in 2009, after soybean and palm².

The main use of rapeseed oil is biodiesel production. This biofuel may be used in pure form in newer engines without damage, and is frequently combined with fossil-fuel diesel in ratios varying from $2 \%$ to $20 \%$ biodiesel. Rapeseed oil is the preferred oil stock for biodiesel

\footnotetext{
2 http:/ / es.wikipedia.org/wiki/Brassica_napus
} 
production in most of Europe, partly because rapeseed produces more oil per unit of land area compared to other oil sources, such as soy beans ${ }^{3}$.

Helianthus tuberosus L. ("Jerusalem artichoke", "sunroot", "sunchoke" or "topinambur") is a species of sunflower native to North America, and long used by the American Indian for food. It has been introduced and became naturalized in all temperate regions in the Northern and Southern Hemispheres. It is also cultivated widely across the temperate zone for its tubers, which are used as root vegetable (Duke J., 1983).

It is an herbaceous perennial plant growing to $1.5-3 \mathrm{~m}$ tall. The flowers are yellow, produced in capitate flowerheads which are $5-10 \mathrm{~cm}$ in diameter. The tubers are elongated and uneven, typically $7.5-10 \mathrm{~cm}$ long and $3-5 \mathrm{~cm}$ thick, and vaguely resembling ginger root, with a crisp texture when raw. They vary in color from pale brown to white, red or purple (Huxley, et al., 1992).

The main uses of Jerusalem artichoke are: horticulture, forage and industry (inulin extraction and ethanol production).

\subsection{Waste-water use in energy crops production: our experiences}

We conducted a trial in which yield and potential to produce ethanol of Jerusalem artichoke and yield and potential to produce biodiesel of a winter rape cultivar were compared. Two types of irrigation: urban waste water (UWW) and ground water (GW) were used (Table 1). Both researches were conducted in the Urban Waste Water Treatment Plant of Obras

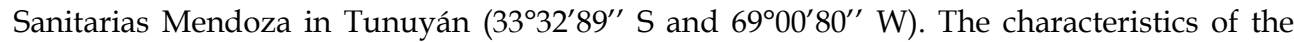
soil of the trial are shown in table 2 .

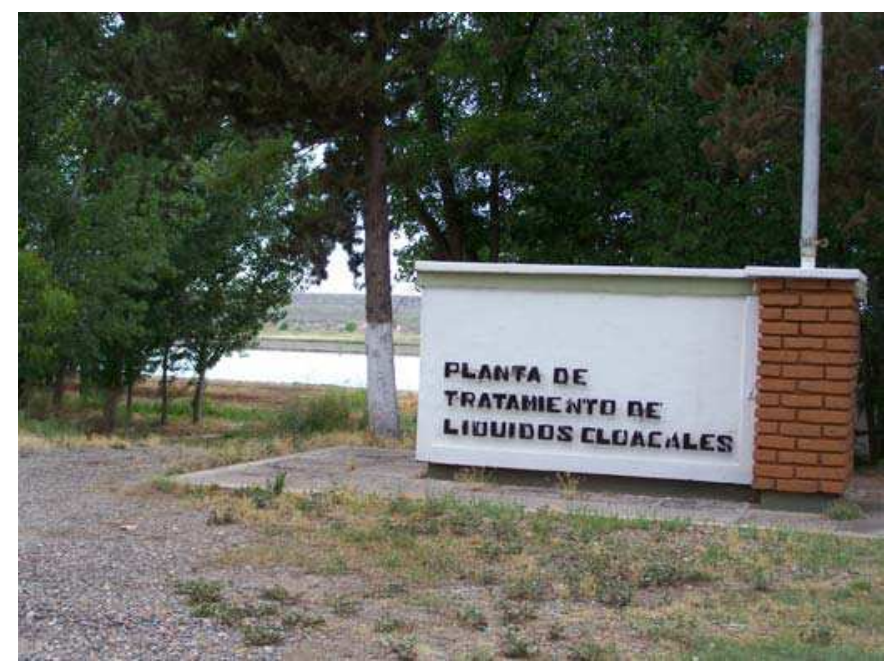

Photo 4. Urban Waste Water Treatment Plant of Obras Sanitarias Mendoza in Tunuyán; the treatment pools are behind the trees.

\footnotetext{
${ }^{3}$ http:/ / www.openmarket.org/2007/11/12/biofuel-mandates-cause-global-warming-scientists-say/
} 


\begin{tabular}{ccc}
\hline Parameter & GW & UWW \\
\hline Electrical conductivity $(\mathrm{dS} / \mathrm{M})$ & 0.42 & 1.10 \\
Total nitrogen $(\mathrm{mg} / \mathrm{l})$ & 5.6 & 28.7 \\
Mineral nitrogen, $\mathrm{NH}_{4}+\mathrm{NO}_{3}(\mathrm{mg} / \mathrm{l})$ & 1.05 & 14.7 \\
Phosphorus, $\mathrm{P}(\mathrm{mg} / \mathrm{l})$ & 0.13 & 11.51 \\
Phosphorus, $\mathrm{PO}_{4}-3(\mathrm{mg} / \mathrm{l})$ & 0.39 & 35.3 \\
Potassium, $\mathrm{K}_{(\mathrm{mg} / \mathrm{l})}$ & 11 & 20 \\
Potassium, $\mathrm{K}_{2} \mathrm{O}(\mathrm{mg} / \mathrm{l})$ & 13.2 & 24 \\
Organic matter $(\mathrm{mg} / \mathrm{l})$ & 73.4 & 236 \\
\hline
\end{tabular}

Table 1. Characterization of irrigation waters, ground water $(\mathrm{GW})$ and urban waste water (UWW)

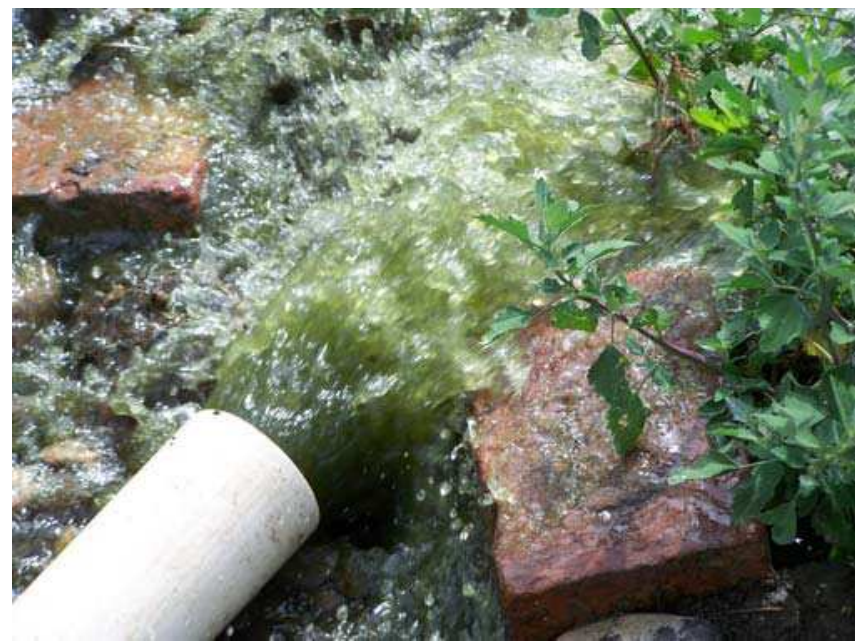

Photo 5. Appearance of the waste water used for irrigation.

\begin{tabular}{lcc}
\hline \multicolumn{1}{c}{ Variable } & \multicolumn{2}{c}{ Soil Condition } \\
\hline Depht $(\mathrm{cm})$ & $0-10$ & $10-30$ \\
$\mathrm{pH}$ & 6.63 & 6.76 \\
Electrical conductivity $(\mathrm{dS} / \mathrm{M})$ & 19.80 & 12.20 \\
Saturation percentage $(\mathrm{g} \% \mathrm{~g})$ & 35 & 49.8 \\
sedimentation volume $(\mathrm{ml} \% \mathrm{~g})$ & 116 & 124 \\
Total nitrogen $(\mathrm{mg} / \mathrm{kg})$ & 5570 & 3780 \\
Phosphorus $(1: 10)(\mathrm{mg} / \mathrm{kg})$ & 26.2 & 13.3 \\
Exchangeable Potassium $(\mathrm{mg} / \mathrm{kg})$ & 1149 & 740 \\
Organic matter $(\mathrm{g} \% \mathrm{~g})$ & 9.2 & 6.2 \\
C/N Relationship & 9.6 & 9.5 \\
\hline
\end{tabular}

Table 2. Soil characterization 


\subsection{Jerusalem artichoke trial}

\subsubsection{Materials y methods}

Two cultivars of Jerusalem artichoke were tryed (red tubers, $\mathbf{R}$, and white tubers, $\mathbf{W}$ ), and two kinds of waters were used for irrigation (urban waste water, $\mathbf{U W W}$, an ground water, GW).

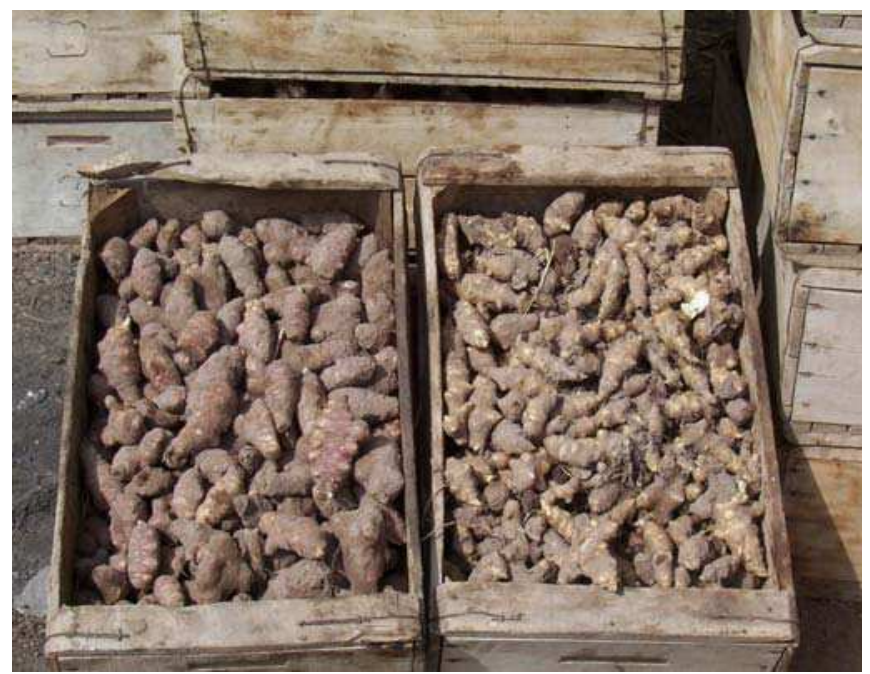

Photo 6. Tubers of the two Jerusalem artichoke cultivars tryed in this experience. R, with red tubers, in the left; and $\mathrm{W}$, with white tubers, in the right.

The experimental test had a random plot design, with 3 repetitions per treatment (each combination of cultivar and kind of water). The planting density was 25,000 plantas/hectares; $0.8 \mathrm{~m}$ between rows and $0.5 \mathrm{~m}$ between plants in the row. The tubers seed weight was around $50 \mathrm{~g}$, and planting depth was $10 \mathrm{~cm}$. It was carried out manual weed control and we did weekly irrigations with $22 \mathrm{~mm}$ of water (35 applications in total $=767$ $\mathrm{mm}$ ). We harvested individual crop plants and in each one, the following parameters were determined:

- Performance of tubers per plant $(\mathrm{kg})$

- Number of tubers per plant

- Height (m)

- Number of main stems

- Performance of dry biomass $(\mathrm{kg})$. On a sample of biomass combustion heat was determined, with a calorimeter bomb.

In laboratory, we estimated the potential to produce bioethanol from tubers, taking into account the following relationship: for each $\mathrm{kg}$ of fermentable carbohydrates, $0.5563 \mathrm{l}$ of ethanol is obtained ${ }^{4}$.

\subsubsection{Results}

Jerusalem artichoke tuber yield showed differences between type of water treatment, being $177,750 \mathrm{~kg} /$ hectares in UWW and 144,000 kg/hectares in GW.

\footnotetext{
${ }^{4}$ http://journeytoforever.org/biofuel_library/ethanol_motherearth/meCh2.html
} 


\begin{tabular}{ccc}
\hline Varieties & UWW & GW \\
\hline R & 206,250 & 154,000 \\
W & 149,500 & 134,250 \\
Average & 177,750 & 144,000 \\
\hline
\end{tabular}

Table 3. Tuber yield per hectare $(\mathrm{kg})$ for each irrigation treatment (ground water GW and urban waste water UWW) and for two varieties (R and W).

In both varieties yield was higher when UWW was used for irrigation. R had higher yield than $\mathrm{W}$ variety. Yields in this trial were bigger than those got in Australia when Jerusalem artichoke was irrigated using UWW; Parameswaran (1999) in that country had 120,000 kg tubers/ hectare.

Number of tubers produced per plant was significantly higher in those urban waste water irrigated. Besides, plants belonging to $\mathrm{W}$ variety had significantly more tubers than $\mathrm{R}$ plants. Results can be seen in the following table.

\begin{tabular}{ccc}
\hline Varieties & UWW & GW \\
\hline $\mathrm{R}$ & $94.27 \mathrm{~b}$ & $66.08 \mathrm{~b}$ \\
$\mathrm{~W}$ & $122.53 \mathrm{a}$ & $113.08 \mathrm{a}$ \\
Average & $108.4 \mathrm{a}$ & $89.58 \mathrm{~b}$ \\
\hline
\end{tabular}

Table 4. Number of tubers per plant for each irrigation treatment (ground water GW and urban waste water UWW) and for two varieties (R and W).

Different letters indicate significant differences at $\mathrm{P}=0.05$

Plant height significantly differed between irrigation treatments $(P=0,00001)$, but did not between varieties $(P=0.1257)$. Results are shown in table 5 .

\begin{tabular}{ccc}
\hline Varieties & UWW & GW \\
\hline $\mathrm{R}$ & $3.07 \mathrm{a}$ & $2.56 \mathrm{a}$ \\
$\mathrm{W}$ & $2.87 \mathrm{a}$ & $2.86 \mathrm{a}$ \\
Average & $2.97 \mathrm{a}$ & $2.71 \mathrm{~b}$ \\
\hline
\end{tabular}

Table 5. Plant height $(\mathrm{m})$ for each irrigation treatment (ground water GW and urban waste water UWW) and for two varieties (R and W).

Different letters indicate significant differences at $\mathrm{P}=0.05$

The number of main stems per plant differed significantly betwen kind of irrigation water $(p=0.0013)$, but did not differ between varieties $(p=0.5207)$. Plants irrigated with urban waste water had more stems than those ground water irrigated (table 6).

\begin{tabular}{ccc}
\hline Varieties & UWW & GW \\
\hline $\mathrm{R}$ & $1.47 \mathrm{a}$ & $1.39 \mathrm{a}$ \\
$\mathrm{W}$ & $1.62 \mathrm{a}$ & $1.32 \mathrm{a}$ \\
Average & $1.54 \mathrm{a}$ & $1.35 \mathrm{~b}$ \\
\hline
\end{tabular}

Table 6. Number of main stems per plant for each irrigation treatment (ground water GW and urban waste water UWW) and for two varieties (R and W).

Different letters indicate significant differences at $\mathrm{P}=0.05$ 
Dry aerial biomass per plant differed between irrigation treatments $(P=0.00001)$ and between varieties $(P=0.0125)$. It was higher in plots irrigated with $U W W$ and in $R$ variety, as can be seen in table 7 .

\begin{tabular}{ccc}
\hline Varieties & UWW & GW \\
\hline $\mathrm{R}$ & $0.87 \mathrm{a}$ & $0.58 \mathrm{a}$ \\
$\mathrm{W}$ & $0.71 \mathrm{~b}$ & $0.62 \mathrm{a}$ \\
Average & $0.79 \mathrm{a}$ & $0.60 \mathrm{~b}$ \\
\hline
\end{tabular}

Table 7. Aerial dry biomass per plant $(\mathrm{kg})$ for each irrigation treatment (ground water GW and urban waste water UWW) and for two varieties (R and W).

Different letters indicate significant differences at $\mathrm{P}=0.05$

The remanent dry aerial biomass of the crop per ha was $23,250 \mathrm{~kg}$ in UWW and 17,750 kg in GW. The combustion heat of it was $3,668 \mathrm{kcal} / \mathrm{kg}$, representing an important energy contribution that can be usefull in the industrial process for obtaining ethanol.

The potential to produce ethanol was 15,000 1/ha in plots irrigated with UWW and 13,000 1/ha in the GW irrigated. Ethanol potential production was estimated from the amount of fermentable carbohydrates in the tubers. To produce 11 of ethanol from tubers, $11 \mathrm{~kg}$ were needed, considering that soluble solids in tubers were about $16 \%$ (Lelio et al., 2009).

Tuber yield of both varieties of Jerusalem artichoke urban wastewater irrigated is higher of that found when the crop is ground water irrigated. This high yield is related to more tubers per plant, higher plants, more stems per plant, and higher aerial biomass per plant.

\subsection{Rape trial}

In this work yield and potential to produce biodiesel of a winter rape cultivar under two irrigation treatments (urban waste water (UWW) and ground water (GW)) were compared.

\subsubsection{Materials and methods}

The experimental test had a random plot design, with 3 repetitions per treatment (each kind of irrigation water, UWW and GW). "Gospel" winter rape cultivar was grown. Sowing date was February $28^{\text {th }}, 2008$, and a density of $8 \mathrm{~kg} /$ hectare was sown, with a distance of $0.4 \mathrm{~m}$ between rows. Each plot had 7 rows of $5 \mathrm{~m}$ long. It was carried out manual weed control and we did weekly irrigations (32 applications in total $=700 \mathrm{~mm}$ ). At the end of November, 2008, the plots were harvested and the following parameters were determined:

- Number of plants per square meter.

- Number of siliqua per plant, on 30 plants randomly taken in each plot.

- Number of seed per siliqua, on 150 siliqua randomly taken in each plot.

- One thousand seeds weight, on five groups of 1000 seeds per experimental plot.

- Seed yield per unit surface. Cut in farm and laboratory threshing.

- $\quad$ Oil in seeds, Soxlhet methodology.

Variance tests were performed to compare the previous parameters.

\subsubsection{Results}

In the following table results of yield components for each irrigation system (UWW and GW) are shown. 


\begin{tabular}{cccc}
\hline \multirow{2}{*}{ Yield component } & \multicolumn{2}{c}{ Kind of irrigation water } & $\begin{array}{c}\text { Significant differences at } \\
5 \% \text { level }\end{array}$ \\
& UWW & GW & No, $\mathrm{p}=0.3603$ \\
\hline $\mathrm{N}^{\mathrm{o}}$ plants $/ \mathrm{m}^{2}$ & $27.5 \pm 4.33$ & $33.32 \pm 8.77$ & Yes, $\mathrm{p}=0.0003$ \\
$\mathrm{~N}^{\mathrm{o}}$ siliqua/ plant & $692.3 \pm 16.80$ & $533.7 \pm 16.62$ & Yes, $\mathrm{p}=0.0048$ \\
$\mathrm{~N}^{\mathrm{o}}$ seeds/ siliqua & $23.07 \pm 0.83$ & $20.48 \pm 0.38$ & Yes, $\mathrm{p}=0.0050$ \\
1000 seeds weight & $3.60 \pm 0.10$ & $2.43 \pm 0.35$ & - \\
$\%$ oil in seeds & 36.7 & 36.2 & - \\
\hline
\end{tabular}

Table 8. Number of plants/ $\mathrm{m}^{2}$, number of siliqua/plant, number of seeds/siliqua, 1.000 seeds weight, oil percentage in seeds in each irrigation treatment (UWW y GW) of rape grown in Tunuyán, 2008.

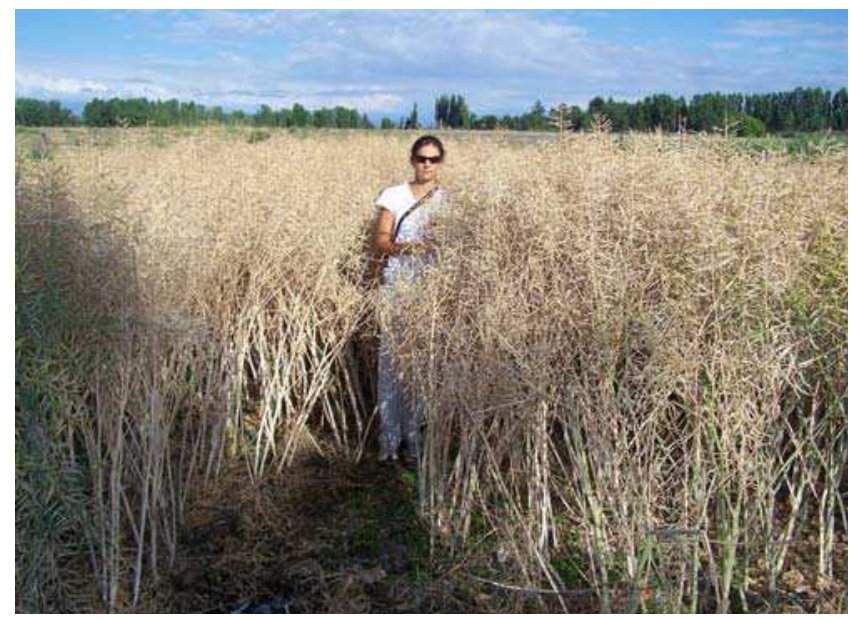

Photo 7. Rape crop before harvest.

As it can be seen in table 8 , number of plants per unit surface did not show significant differences, average was 30.41 plants $/ \mathrm{m}^{2}$; that is between the range recommended for winter cultivars, from 20 to 60 plants $/ \mathrm{m}^{2}$ (Iriarte and Apella, 2007).

The number of siliqua per plant significantly differed between irrigation treatments. We found 692.3 siliqua per plant in UWW plots and 533.7 in GW plots; both higher than values indicated by other authors (Iriarte y Valetti, 2008, Tamagno et al., 1999).

The number of seeds per siliqua differed between UWW and GW irrigation treatments. Siliqua from UWW plots had 23.07 seeds average, while GW siliqua had 20.48 seeds.

One thousand seeds weight presented significant differences. Bigger seeds were produced in UWW compared with GW.

Rape yield can be estimated from yield componentes: number of plants per unit surface, number of siliqua per plant, number of seeds per siliqua, and seeds weight (Gómez and Miralles, 2006). In our trial, yield estimations were $15,811 \mathrm{~kg} /$ hectare in UWW and 8,851 $\mathrm{kg} /$ hectare in GW treatment. 


\section{Harvest plots yield results}

In UWW plots yield was higher $(7,690 \mathrm{~kg} /$ hectare) than in GW plots $(3,886 \mathrm{~kg} /$ hectare). These values of yield are very high; probably associated to the high level of nutrients in the irrigation UWW (Rebora et al., 2010).

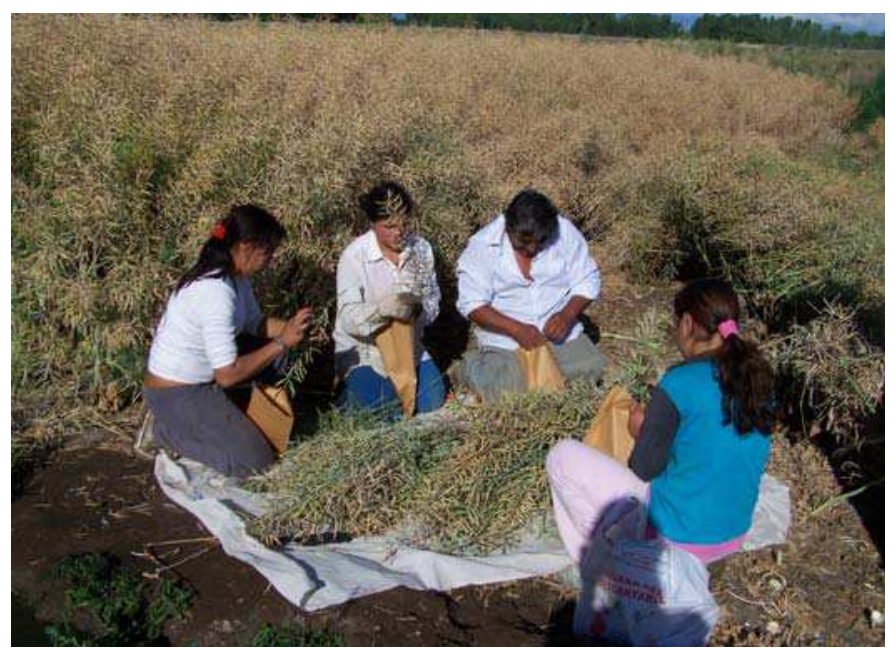

Photo 8. Rape harvest, december 2008.

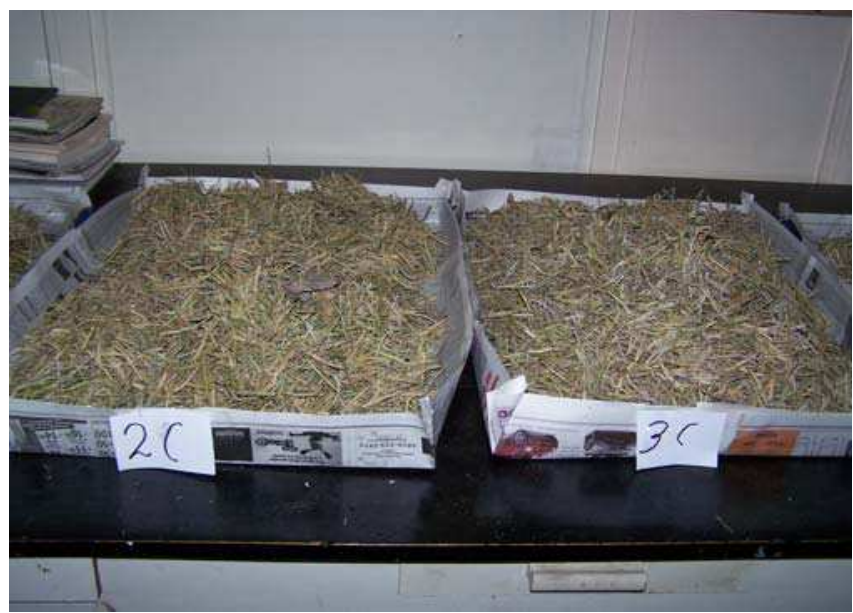

Photo 9. Final dry of siliqua in laboratory.

\section{Oil}

Oil percentage found in seeds of both treatments was lower than that indicated for Gospel cultivar (47\%). It was 36.7 in UWW and $36.2 \%$ in GW seeds. Usually, seed yields are associated with low oil percentage in seeds. Besides, high levels of nitrogen fertilization tend to reduce oil content in seeds. 


\begin{tabular}{ccc}
\hline Variable & \multicolumn{2}{c}{ Kind of irrigation water } \\
& UWW & GW \\
\hline Seed yield (kg/ha) & 7,690 & 3,886 \\
Oil (\%) & 36.7 & 36.2 \\
Oil yield (kg/ha) & $\mathbf{2 , 8 2 2}$ & $\mathbf{1 , 4 0 6}$ \\
\hline
\end{tabular}

Table 9. Oil yield of rape grown under two irrigation treatments (UWW, urban waste water, and GW, ground water) in Tunuyán, Mendoza, 2008.

\section{Biodiesel production}

Every 100 litres oil, 100 litres biodiesel can be obtained (Muñoz, 2005). According to the previous relation, the oil that could be obtained represents the ammount of biodiesel that could be produced per unit surface; this is 2,822 1 biodiesel/hectare when rape is irrigated with urban waste-water and 1,406 litres biodiesel/ha when it is irrigated with ground water. From our results we are able to say that the use of urban waste water in rape irrigation allows to reach very high yields, both of seeds and biodiesel per unit surface.

\section{Conclusions}

In recent years waste-water use has gained importance in water-scarce regions. Wastewater reuse in agriculture is an old practice that has been generally implemented worldwide. Agricultural deployment of wastewater for irrigation is based on the value of its water content and its constituents, which are used as fertilizers. However, crop irrigation with insufficiently treated wastewater may result in health risks. Energy crops, not grown for the purpose of producing food, have no health risks implicated for the consumers. Many crops can be used as energy crops for biofuels (bioethanol and biodiesel) production.

Mendoza province generates $3.2 \mathrm{~m}^{3} / \mathrm{s}$ of domestic efluents. It is estimated that 10,300 hectare are irrigated today with urban waste water with different treatment level. There are still many ha that could be used for energy crops using remanent urban waste-water.

Both "rape" and "Jerusalem artichoke" have shown to be interesting energy crops under urban waste-water irrigation in Mendoza, Argentina, For biodiesel and bioethanol production, respectively.

To conclude, urban waste-water could be used to enlarge oasis in Mendoza, and energy crops such us rape and Jerusalem artichoke present higher yields when they are irrigated with this type of water compared to the yields of those crops using ground water irrigation.

\section{Acknowledgement}

The experimental work shown in this chapter was financially supported by Secretaría de Ciencia, Técnica y Posgrado, Universidad Nacional de Cuyo, Municipalidad de Tunuyán and Obras Sanitarias Mendoza.

The authors thank Gabriela Salvador and Ricardo Masuelli who reviewed the English version. 


\section{References}

Dalla Marta, A., Mancini, M., Ferrise, R., Bindi, M., Orlandini, S. 2010. Energy crops for biofuel production: Analysis of the potential in Tuscany. B i oma s s and b i o e n e rgy 3 4: $1041-1052$.

de Vries, S. C., van de Ven, G. W. J., van Ittersum, M. K., Giller, K. E. 2010. Resource use efficiency and environmental performance of nine major biofuel crops, processed by first-generation conversion techniques. B i o $\mathrm{m}$ a s s and b i o energy 34:588-601.

Duke, J. A. 1983. Handbook of Energy Crops. http://www.hort.purdue.edu/newcrop/duke_energy/Helianthus_tuberosus.html

Ensink, H.H., Mehmood, T., Vand der Hoeck, W., Raschid-Sally, L., Amerasinghe, F.P., 2004. A nation-wide assessment of wastewater use in Pakistan: an obscure activity or a vitally important one? Water Policy 6, 197-206.

Fulton, L., Howes, T., Hardy, J. 2004. Biofuels for transport: an international perspective. International Energy Agency, Paris, France. In: http://www.iea.org/textbase/nppdf/free/2004/biofuels2004.pdf

Gómez, N., Miralles, D. 2006. Colza. Capítulo 2.4, en: Cultivos industriales. Editorial Facultad de Agronomía. UBA.

Guevara, J. C., Cavagnaro, J. B., Estevez, O. R., Le Houérouf, H. N. and C. R. Stasi. 1997. Productivity, management and development problems in the arid rangelands of the central Mendoza plains (Argentina). Journal of Arid Environments Volume 35, Issue $4,575-600$.

Gupta, N., Khan, D.K., Santra, S.C. 2009. Prevalence of intestinal helminth eggs on vegetables grown in wastewater-irrigated areas of Titagarh, West Bengal, India. Food Control 20: 942-945.

Huergo, H. 2001. El biodiesel, una contribución de agro para mejorar el medio ambiente. Bolsa de Cereales 3026: 3-5.

Huxley, A. J., Griffiths, M. and M. Levy. 1992. The New Royal Horticultural Society dictionary of gardening. London: Macmillan Publishers. ISBN 0333474945. OCLC 29360744.

Iriarte, L., C. Appella. 2007. Densidad de siembra en cultivares invernales. Campaña 2007. Chacra Experimental Integrada Barrow. Capítulo 7: Tecnología del cultivo. Cultivo de colza. Editores Iriarte L., y O. Valetti. Chacra Experimental Integrada Barrow. Convenio MAAyP- INTA.

Iriarte, L., Valetti, O., 2008. Cultivo de colza. Editores Iriarte L., y O. Valetti. Chacra Experimental Integrada Barrow. Convenio MAAyP- INTA.

Kays, S. J. \& Nottingham, S. F. 2008. Biology and Chemistry of Jerusalem Artichoke Helianthus tuberosus L. Ed. CRC Press.

Keraita, B.N., Drechsel, P., 2004. Agricultural use of untreated urban wastewater in Ghana. In: Scott, C.A., Faruqui, N.I., Raschid-Sally, L. (Eds.), Wastewater Use in Irrigated Agriculture. CABI Publishing, Wallingford, UK.

Lelio, H., Rebora, C., Gómez, L. 2009. Ethanol potential production from Jerusalem artichoke (Helianthus tuberosus L.) irrigated with urban waste water. Revista FCA- UNCuyo. Tomo XLI (1): 123-133.

Mexico CAN (Comision Nacional del Agua), 2004. Water Statistics. National Water Commission, Mexico City.

Muñoz, C. M. 2005. El biodiesel como solución energética. Revista Agromercado 248, pág. 6-8. 
Parameswaran, M. 1999. Urban wastewater use in plant biomass production. Resourses, Conservation and Recycling, 27: 39-56.

Pedrero, F., Kalavrouziotis, I., Alarcón, J. J., Koukoulakis, P. , Asano, T. 2010. Use of treated municipal wastewater in irrigated agriculture. Review of some practices in Spain and Greece. Agricultural Water Management 97: 1233-1241.

Pin Koh, L., Ghazoul, J. 2008. Biofuels, biodiversity, and people: Understanding the conflicts and finding opportunities. B I O LO G I CA L C O NS E RVAT IO N 1 4: 2450 -2 4 60.

Qadir, M., Wichelns, D., Raschid-Sally, L., McCornick, P. G., P. Drechsel, P., Bahri, A., Minhas, P. S. 2010. The challenges of wastewater irrigation in developing countries. Agricultural Water Management 97 (2010) 561-568.

Rebora, C., Lelio, H., Gómez, L. 2010. Use of urban waste water in rape (Brassica napus L.)production destinated to biofuel. Revista FCA- UNCuyo, Tomo 42. No 1, 207-212.

Shi R., Peng S., Wang Y., Zhang H., Zhao Y., Liu F. and Zhou Q. 2008. Countermeasures of Reclaimed Municipal Wastewater for Safety of Agricultural Use in China. Agricultural Sciences in China, 7(11): 1365-1373.

Singh J, Panesar BS, Sharma SK. 2008. Energy potential through agricultural biomass using geographical information system -a case study of Punjab. Biomass and Bioenergy; 32:301-7.

Tamagno, L.. N., Chamorro, A. M., S. J. Sarandón. 1999. Aplicación fraccionada de nitrógeno en colza (Brassica napus L.): efectos sobre el rendimiento y la calidad de la semilla. Revista de la Facultad de Agronomía de La Plata, 104 (1): 25-34. 


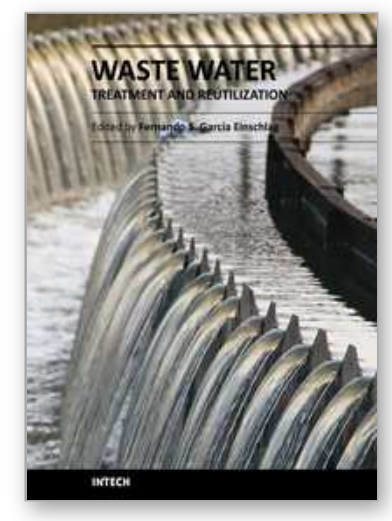

\author{
Waste Water - Treatment and Reutilization \\ Edited by Prof. Fernando Sebastiẽ̃in GarcÃa Einschlag
}

ISBN 978-953-307-249-4

Hard cover, 434 pages

Publisher InTech

Published online 01, April, 2011

Published in print edition April, 2011

The steady increase in industrialization, urbanization and enormous population growth are leading to production of huge quantities of wastewaters that may frequently cause environmental hazards. This makes waste water treatment and waste water reduction very important issues. The book offers a collection of studies and findings concerning waste water treatment, minimization and reuse.

\title{
How to reference
}

In order to correctly reference this scholarly work, feel free to copy and paste the following:

Cecilia Rebora, Horacio Lelio, Luciana Gómez and Leandra Ibarguren (2011). Waste-Water Use in Energy Crops Production, Waste Water - Treatment and Reutilization, Prof. Fernando SebastiÃ $i n$ GarcÃa Einschlag (Ed.), ISBN: 978-953-307-249-4, InTech, Available from: http://www.intechopen.com/books/waste-watertreatment-and-reutilization/waste-water-use-in-energy-crops-production

\section{INTECH}

open science | open minds

\author{
InTech Europe \\ University Campus STeP Ri \\ Slavka Krautzeka 83/A \\ 51000 Rijeka, Croatia \\ Phone: +385 (51) 770447 \\ Fax: +385 (51) 686166 \\ www.intechopen.com
}

\author{
InTech China \\ Unit 405, Office Block, Hotel Equatorial Shanghai \\ No.65, Yan An Road (West), Shanghai, 200040, China \\ 中国上海市延安西路65号上海国际贵都大饭店办公楼405单元 \\ Phone: +86-21-62489820 \\ Fax: +86-21-62489821
}


(C) 2011 The Author(s). Licensee IntechOpen. This chapter is distributed under the terms of the Creative Commons Attribution-NonCommercialShareAlike-3.0 License, which permits use, distribution and reproduction for non-commercial purposes, provided the original is properly cited and derivative works building on this content are distributed under the same license. 